\title{
Development and Sustainability of Vegetable Farming in Geothermal Greenhouses: A Case Study of Nigorikawa Area in Mori Town, Hokkaido
}

\author{
UMEDA Katsuki \\ Faculty of Letters, Hokkaido University, Sapporo 060-0810, Japan
}

\begin{abstract}
This study attempts to clarify the formation of a geothermal greenhouse agricultural area in northern peripheral Japan, and to examine the sustainability of intensive agriculture in terms of its ability to develop natural energy sources. The study area, Nigorikawa in Mori Town, is a pioneering production center of tomatoes grown in greenhouses in Hokkaido. The success relied on intensive utilization of geothermal resources for agricultural purposes, which made economic sense because the rights of access to hot springs were almost of no value. It became possible to pursue high profitability by specializing in tomato growing. However, it is now difficult to maintain sustainability as a production center due to excessive drawing up of water for 827 greenhouses. This depletion of geothermal resources makes it difficult to expand tomato farming. On the other hand, negative side effects of repeated cultivation became worse as rotation farming systems were abandoned in pursuit of profitability. It is also unavoidable to use large amounts of chemicals, which is disliked by consumers. Thus, tomatoes produced in Nigorikawa seem to be lacking superiority in terms of both price and quality. The best strategy to develop tomato production is to create higher added value by pursuing high-quality produce with significantly reduced utilization of chemicals. Consumer demands for "safe and secure" agricultural products are growing rapidly. It is necessary to shift from the mass-producing and mass-consuming system that formed the basis of Hokkaido's agricultural industry in the 20th century, to the sustainable and environmentally harmonic system for the 21 st century that prioritizes quality and safety.
\end{abstract}

Key words: tomato, greenhouse agriculture, geothermal resource, sustainability, peripheral region, Nigorikawa area in Mori Town

\section{Introduction}

The importance of the energy issue in agriculture is increasing sharply accompanying the jump of the oil price. ${ }^{1}$ Industrialized agriculture depends on petroleum resources strongly, as it is almost impossible to gain farm production without agricultural machines and chemical fertilizers. The rising prices of agricultural inputs accompanying crude oil causes a steep rise in the production cost. It is especially serious in greenhouse agriculture with a high rate of heat, light and power expenses. Greenhouse agriculture is the most typical section which combines the three elements of concentralization, intensification and specialization explained as "agricul- tural industrialization" (Bowler 1992). Takesono (2002) points out that the soaring energy price is the main factor of the increase in costs, as heat, light and power expenses per 10a in greenhouse agriculture has increased by 10 times in 15 years after 1985 . The cost reduction by energy saving has been indispensable to increase competitiveness in greenhouse agriculture. Although there is advanced technology for energy saving in Japan, there is a limit in cost reduction as long as it depends on oil.

In some developed countries, the development of alternative energy sources to oil with few environmental impacts has been promoted. The alternative energy sources currently most utilized for agriculture are geothermal resources. Southern and eastern Europe are the most advanced 


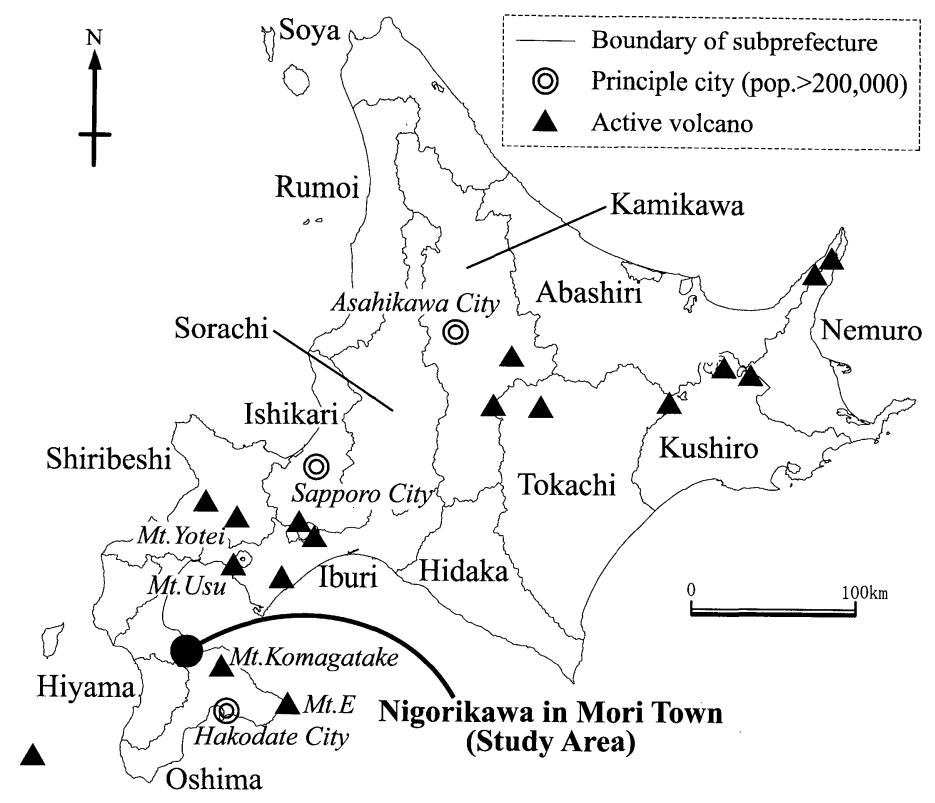

Figure 1. Location map of study area.

regions to use geothermal resources in the world (Popovski and Popovska-Vasilevska 2003). Agricultural use occupies $18.4 \%$ of geothermal energy use in Europe. The largest geothermal greenhouse complex in the world is in Padana valley in northern Italy (Facchini et al. 1993). Technical development for the exploitation of geothermal energy is also honestly continued in Europe (Popovski and Popovska-Vasilevska 2001). It is widely used also in New Zealand (Lund and Klein 1995) and the western part of the United States (Lund and Boyd 2000).

Some areas are utilizing geothermal energy even in Japan. However, there are few areas currently utilized geothermal resource because uneven distribution and instability make it relatively unpopular. As Japan, located in the circum-Pacific orogenic zone, also has abundant geothermal resources including many volcanoes, the potential availability in some areas is very high. The area with the highest potential is Hokkaido. Hot springs now number 245 and are located all over Hokkaido except in Hidaka and Rumoi subprefectures (Figure 1). According to the Health and Welfare Department of Hokkaido, the hot springs produce $400,000 \mathrm{kl}$ of hot water each day, which makes up a little more than 10\% of the national total. Although much of this water comes from high-temperature wells, only about 900 of these high-temperature wells are actually in use; the remaining 1,370 wells, more than $60 \%$, are unused. Moreover, $45 \%$ of Hokkaido's hot springs are flowing wells, compared to the national average of $30 \%$. This means that the possibility of multiple-purpose use of hot spring sources is relatively high.

Geothermal resources in Hokkaido are widely distributed and rich both in quality and quantity, and many of the secondary uses are performed. The most common secondary use of geothermal resources is for agriculture. It makes use of hot spring water to warm glass and plastic greenhouses. According to Fujimoto (1997) and Fujimoto and Matsunami (1999) who estimated Hokkaido's geothermal energy consumption (i.e. installed capacity) by use, the largest user was the agricultural industry, consuming $48 \%$ of the total and replacing $2.8 \mathrm{kl}$ of kerosene annually. Geothermally heated greenhouses cover $269,000 \mathrm{~m}^{2}$ in 31 municipalities across Hokkaido. However, these are unequally distributed, with $78 \%$ of the total concentrated in Mori Town (Oshima Subprefecture), Shihoro Town (Tokachi Subprefecture), and Sobetsu Town (Iburi Subprefecture) (Figure 2). Furthermore, 62\% of the geothermal energy consumed in Hokkaido 


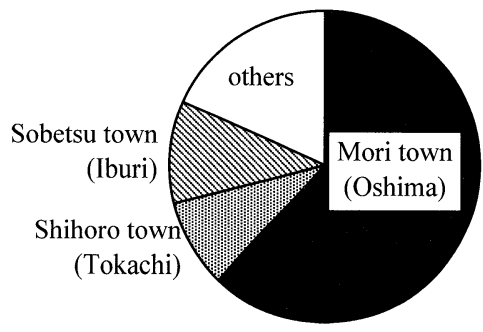

Figure 2. Energy use for geothermal greenhouse.

Source: The Geological Survey of Hokkaido (1999).

for agricultural purposes is concentrated in the Nigorikawa caldera, Mori town. In Nigorikawa caldera, which is only $6 \mathrm{~km}^{2}$ in size, few farmers use kerosene heaters to make up for a shortage of geothermal resources. This means it is quite efficient to consume geothermal energy. Hokkaido Electric Power Co., Inc. also operates the Mori geothermal power station with a declared generating power of $50,000 \mathrm{kw}$ which is one of the largest such facilities in Japan. Thus, Nigorikawa is one of the most advanced areas to achieve large-scale, efficient secondary use of geothermal energy (Kamano 2000, Kurozumi and Doi 2003).

This study will clarify the basis for and development of agricultural use of geothermal resources in Nigorikawa area, and examine the sustainability of geothermal greenhouse agriculture in terms of its ability to develop natural energy sources. In the analysis, the author will pay attention to the social characteristics of Hokkaido, that is both the peculiarity of social relationships on account of reclaimed land and the restrictions on land use on account of the peripheral nature of the region. The concrete procedure is as follows. First, the author clarifies the feature of Nigorigawa area as a farming place of greenhouse tomato production by showing the present condition of greenhouse agriculture in Hokkaido and its role in Japan. Next, the formation process of farming place of greenhouse tomato production increasingly using geothermal resource in Nigorigawa area is described. A solution to the factor of formation of a tomato producing center is considered by paying attention especially both to the conditions of location as a hot spring tourist resort and to the singularity of the rights to the hot spring. Also crop selection and sales strategy to enable between-season shipment are examined. Based on the above analysis, the author examines the sustainability of future greenhouse agriculture in Chapter 4, with a view to all industries depending on natural resources. The main data sources used for this study are existing statistics and interviews of New Hakodate Agricultural Cooperative Association and many farmers in the Nigorikawa area.

Indeed, it may be a unique example to pursue higher added value as a vegetable farming center in Hokkaido, a typical peripheral region in Japan. It is an undeniable fact that Hokkaido's agriculture in the 20th century has developed under the regime of mass-producing and massconsuming of standardized agricultural products. However, it is also a fact that Hokkaido agriculture is in need of the new growing regime in the face of fierce competition from imported crops. Pursuit of a tendency to heighten added value will be set as one effective choice. In this sense, it is expected that this study will give effective suggestions in order to clarify an alternative growth strategy, and new prospects of possibility for the difficulties of Hokkaido's agriculture.

\section{Development of Greenhouse Tomato Farming in Hokkaido}

Hokkaido has developed into the principal agricultural region in peripheral Japan, ${ }^{2}$ dominated by full-time farmers with large-scale economies of production (Ishihara 1996). The market for perishable farm products grown in Hokkaido was dramatically expanded by the distribution revolution including reduction of transportation costs, which were accompanied by the development of transportation technology. However, it is really difficult to improve quality in Japan's other farming regions that have traditionally produced crops. Hokkaido's agricultural industry, developed through the mass production of low-cost agricultural products, is also facing fierce competition from imported crops. Lower prices for agricultural products are seriously affecting farming incomes for large-scale singlecrop farmers.

These problems can be overcome in two ways. One is to attempt to further reduce production 




Figure 3. Transition of the planted area in each crops of institution horticulture in Hokkaido. Source: Department of Agriculture, Hokkaido.

costs by expanding the average cultivated acreage per farm. The other is to produce highvalue-added agricultural products. It is extremely difficult to reduce production costs because of Japan's high labor, agricultural equipment and chemical costs (Sakamoto 2002). Some farming regions in Hokkaido should adopt the latter strategy of higher-value-added products, as it is nearly impossible for all of the agricultural products produced in Hokkaido to survive price competition. A number of new farming places of greenhouse production have been established in Hokkaido as a result of plastic greenhouse construction in crop-rotated rice paddies and the use of reasonably priced tunnel greenhouses. It was also effective to make up for the shortfall of local produce in winter, to heighten the land utilization rates throughout the year, and to increase the gross income of agricultural producers.

The gross area of greenhouse agriculture in Hokkaido has rapidly increased from the mid1980s to the mid-1990s (Figure 3). The driving forces to bring rapid growth in the latter half of the 1980s were melon and spinach. Development of melon farming was brought about by the success of "Yubari melon" which established a nationwide brand, and spinach production grew rapidly by between season shipment (Araki 1996). However, melon and spinach production began to decrease in the mid-1990s with the appearance of rival producing areas and the collapse of the bubble economy. In contrast, green- house tomato is growing rapidly in recent years as if to compensate for the decrease of melon and spinach. Now, it is estimated that greenhouse tomato occupies $20 \%$ in planted area of the whole greenhouse agriculture, and has developed as one of the major 3 crops of greenhouse agriculture with melon and spinach.

Until the 1960s, tomato was a seasonal vegetable provided only in summer, and nearly the whole quantity was consumed in the local market as long-haul transportation had difficulty with technology. In Hokkaido around 1980, quantity of production of tomato was equally divided into 3 types, garden farming, greenhouse farming, and tunnel house farming (utilizing a simple and small vinyl house to assist heating). But the ratio of greenhouse farming increased rapidly in the 1980s with year-round consumption of vegetable (Figure 4). Furthermore, a rapid growth reaching $10 \%$ per year was accomplished from 1994 just after the collapse of the bubble economy. This rapid growth was led by Mori town in Oshima subprefecture in the early years, and by Biratori town in Hidaka subprefecture in the later years. A number of small and middle-sized farming places of greenhouse tomato were established in Kamikawa, Sorachi, and Shiribeshi regions (Figure 5).

The driving force in the formation and growth of greenhouse tomato farming areas was the rapid increase of between seasons shipment and long-distance shipment. As for the volumes of tomatoes shipped by area of production, ship- 


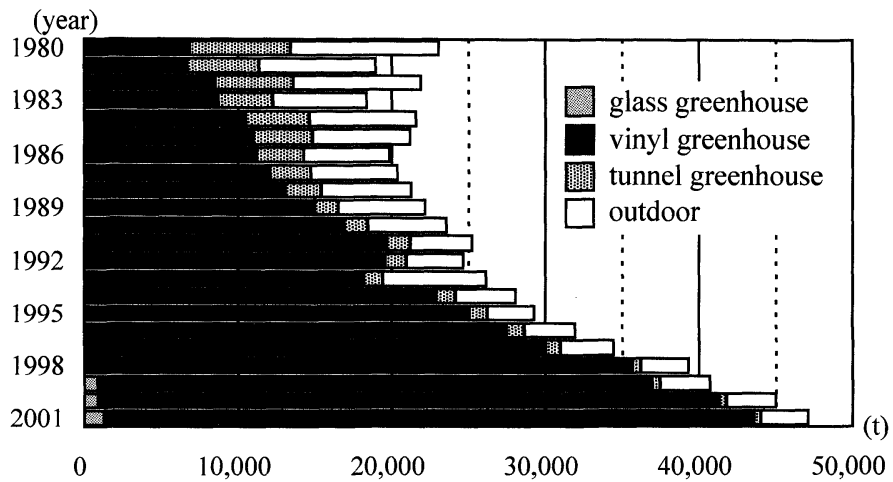

Figure 4. Transition of the tomato planted area classified by cultivation techniques in Hokkaido. Source: Department of Agriculture, Hokkaido.

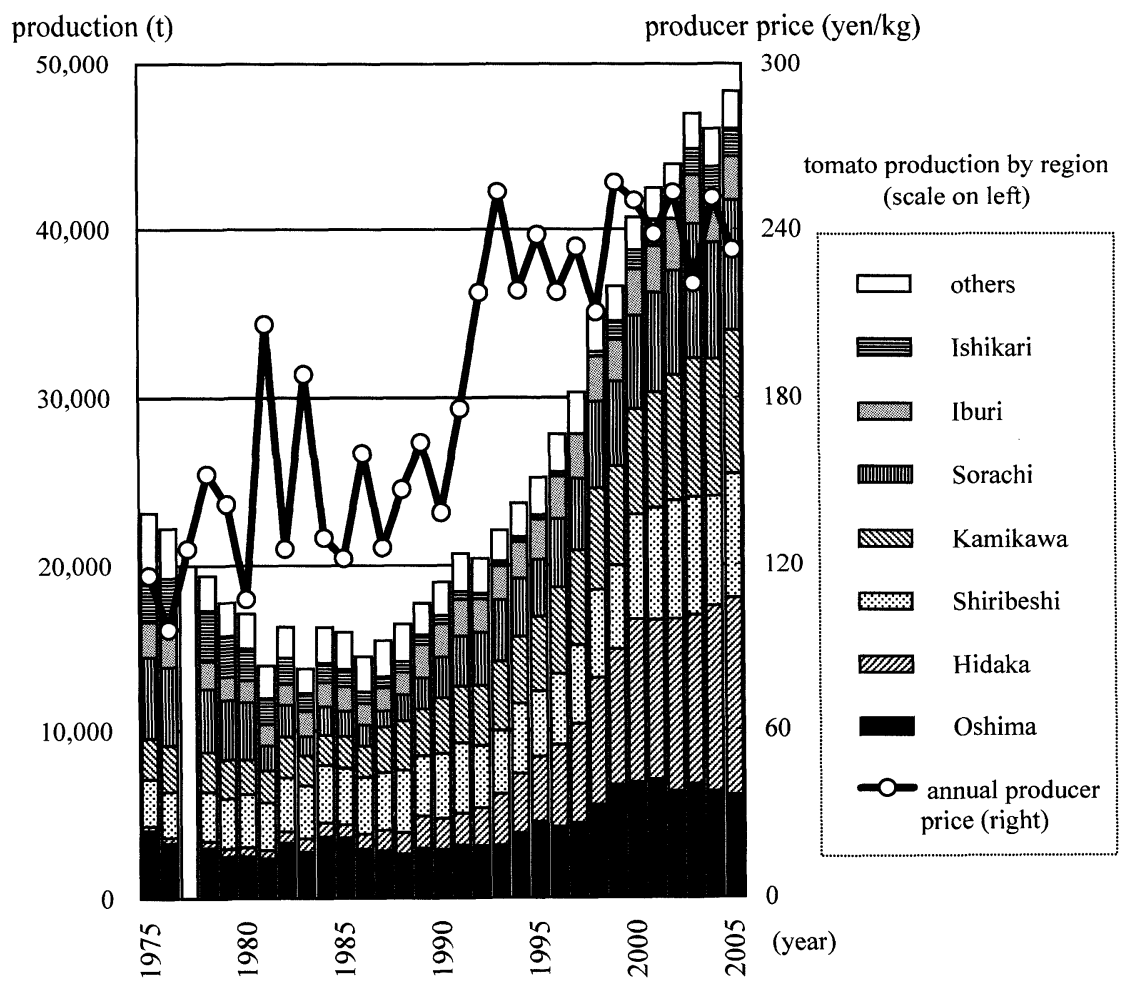

Figure 5. Transition of the producer price and production by region of tomato in Hokkaido. Source: Annual Report of Agriculture, Forestry and Fishery Statistics in Hokkaido.

ping quotas were allocated among production areas depending on the shipping period (Figure 6). For example, in the Tokyo market, tomatoes grown in local (Kanto) spring greenhouses begin to appear around March. From late May, these are gradually replaced by local tomatoes grown outdoors. Those grown in cold regions such as Tohoku and Hokkaido appear in July, and local autumn tomatoes appear after September. From November to March, when the cold weather intensifies, the market is dominated by greenhouse tomato from warm districts such as Kumamoto and Aichi prefectures. Among this allocation by season, tomato production in Hokkaido occupies the largest share (nearly 20\%) from July to August. 


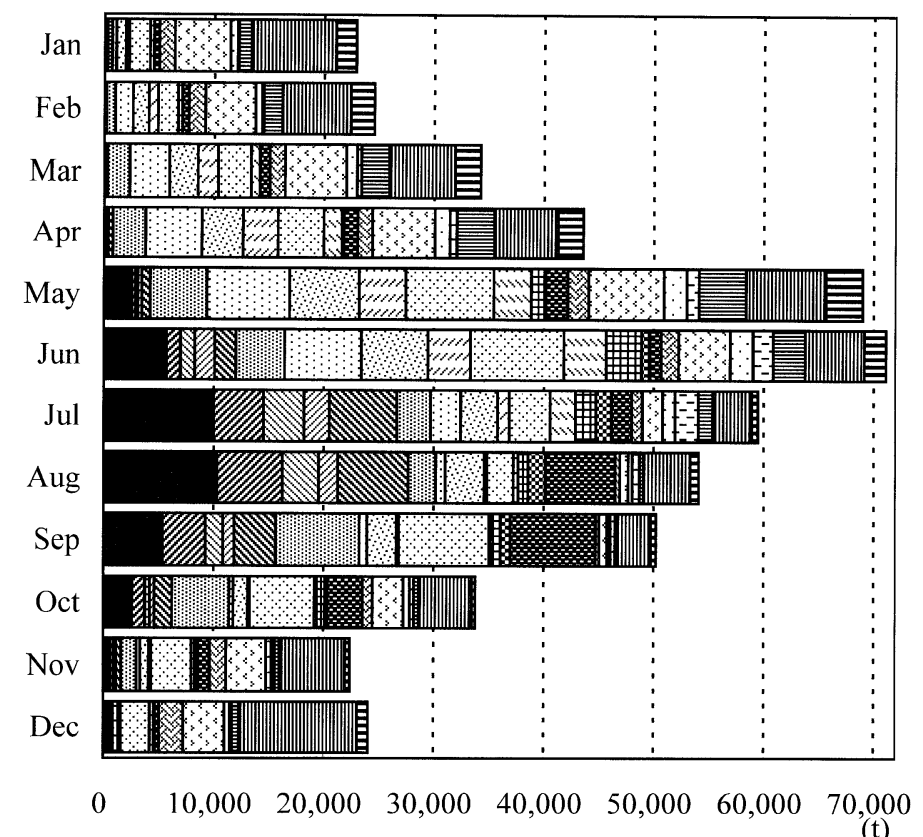

Hokkaido
Aomori
Iwate
Yamagata
Fukushima
Ibaragi
Tochigi
Gunma
Saitama
Chiba
Kanagawa
Niigata
Nagano
Gifu
Shizuoka
Aichi
Mie
Hyogo
Fukuoka
Kumamoto
Miyazaki

Figure 6. Tomato production by season and prefecture (for raw eating only). Source: Hokkaido Regional Development Bureau.

However, the long-distance shipment of greenhouse tomato is a recent attempt, starting with Mori agricultural cooperative association in Oshima subprefecture in 1990. Many producing areas in Hokkaido followed to ship greenhouse tomato towards Kanto market in the season of short supply. The price of tomato has been keeping an upward trend up to today because the cultivation techniques have improved relatively and year-round consumption has progressed dramatically. Now, the quantity of tomato production in Hokkaido exceeds $48,000 \mathrm{t}$ which occupies $7 \%$ of the national total, and $93 \%$ of $48,000 \mathrm{t}$ is produced in greenhouses (Figure 7). The rapid development of greenhouse agriculture is mainly supported by shipment towards outside Hokkaido, which accounts for more than half of tomato production. In 2003, the amount of produce shipped towards outside Hokkaido had grown to seven times the amount in 1996. In the Osaka market, in particular, where there are no dominant tomato production centers in any of the surrounding prefectures, the market share of tomatoes made in Hokkaido reaches $40 \%$ in some months. Hokkaido has thus become one of the principal prefectures for greenhouse tomato, which is indispensable for stabilization of tomato supply in Japan.

\section{Development of Geothermal Greenhouse Agriculture in Nigorikawa}

As mentioned above, Hokkaido grew to become the principal producing area of greenhouse tomato. This is considered to be a result of the strategies for pursuing products with higher added value, which is realized by conquering, or conversely utilizing, the handicap of geographical periphery and the cold climate. The only exception is the Nigorigawa area in Mori Town of Oshima Subprefecture. That is, 53 farms in Nigorikawa have secured high profitability by means of adopting a strategy not only to pursue products with higher added value but also to further reduce production costs by using natural energy sources such as the heat from geothermal hot water and hot springs. It may be considered a unique case in the entire agriculture region of Hokkaido, which is dominated by large-scale fulltime farmers. Farmers in Hokkaido, however, should realize the fact that pursuing economies of scale is not the only method to gain benefit 


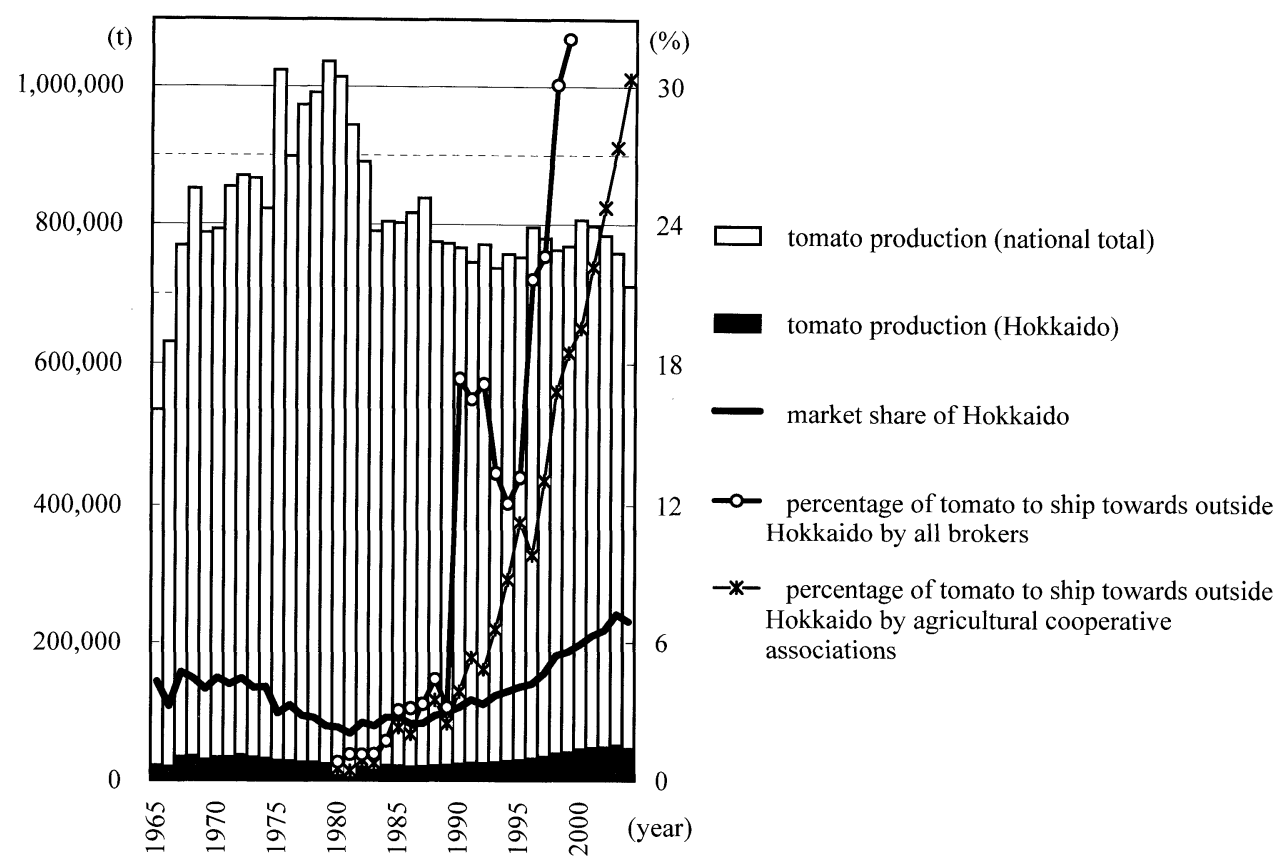

Figure 7. Tomato production and its market.

Source: Department of Agriculture, Hokkaido.

from agriculture in a peripheral region. In this sense, the case of Nigorikawa should be observed as a precious example which can suggest an alternative possibility for agriculture in Hokkaido.

\section{Overview of Nigorikawa area}

Nasu Volcanic Range runs through the eastern part of Oshima Peninsula, jutting out from southwestern Hokkaido. Active volcanoes such as Mt. Komagatake and Mt. E regularly erupt, and numerous hot springs are found flowing throughout the region. Nigorikawa area is included in this region; it sits at the bottom of the Nigorikawa caldera which was formed by a huge eruption approximately 12,000 years ago. The bottom of the caldera with a diameter of $2.5 \mathrm{~km}$ has approximately 160 water-abundant hot spring sources, including flowing wells. A geothermal reservoir with which to build a geothermal power station is favorably located.

Nigorikawa area is located approximately $50 \mathrm{~km}$ north of Hakodate city, and has 397 residents in 110 households, most of whom are descendants of settlers from Toyama and Aichi prefectures with a strong sense of solidarity (Nakajima 1984). Despite an higher aging rate
(23.6\%), some have returned after getting married and as a result the overall demographic composition is now well balanced. The area has an elementary school, a branch office of an agricultural cooperative and a post office, giving the impression that Nigorikawa area is vigorous as an inland agricultural community in Hokkaido.

The economic vigor in Nigorikawa area comes from greenhouse agriculture using geothermal resources. Of the 110 households, 71 are engaged in agriculture. ${ }^{3}$ Because of the number of extended families including three-generation families, the farming population forms $81.1 \%$ of the total. Furthermore, 53 commercial farms have full-time male workers under 60 years of age; 50 of these farms operate geothermal greenhouses, while the remaining 3 raise pigs. This number (50) is almost the same as the number of farmers (51) operating 827 geothermal greenhouses in Nigorikawa area. Therefore, except for a small number of pig farmers, the full-time farming families and part-time farmers, who have sufficient labor, operate geothermal greenhouses, while farms headed by elderly people without successors continue to farm paddy rice fields.

Although winter is comparatively warm in 
Hokkaido, it is severe in Nigorikawa area. The first frost of the season is usually in mid-October, the first snow is in early November, and the ground is completely covered in snow by midDecember. In addition, a seasonal wind from the northwest blows throughout the winter, and snowfall in February exceeds $1 \mathrm{~m}$. The temperature is below $0^{\circ} \mathrm{C}$ all winter long, with the daily low falling below $-10^{\circ} \mathrm{C}$ every day. Monthly sunshine falls below 100 hours from November to February. It is therefore impossible to cultivate crops without the use of greenhouses until April, when the snow melts. The average temperature exceeds $15^{\circ} \mathrm{C}$ only during the 3 -month midsummer period, and dense fog sometimes appears in the summer, with cold weather often damaging rice crops (The Geological Survey of Hokkaido 1975). Under these severe conditions, it is not possible to earn a high income solely by land-intensive grain farming. In fact, only large-scale production of such products as potatoes and pumpkins is undertaken in the other areas of Mori Town and surrounding towns. The only reason for the successful maintenance of a population of almost 400 with its major industry as agriculture is geothermal greenhouse agriculture.

\section{Development of geothermal greenhouse agricultural areas}

Nigorikawa area was a typical single-crop ricegrowing region until the $1950 \mathrm{~s} .{ }^{4}$ In the $1960 \mathrm{~s}$, during the rapid economic growth, most farmers eventually faced a management crisis. As there was a widening gap between agriculture and other industries, $80 \%$ of the male work force went to major cities to work in the winter. Only women, children and the elderly were left in Nigorikawa. As the population decreased $30 \%$ in the late 1960 s, the community was on the brink of collapse.

In this situation, the teaching staff at Nigorikawa Junior High School constructed glass greenhouses behind the schoolhouse with the help of local volunteers in 1968. Some flowers and plants were grown as part of aesthetic cultivation programs. When the plants were found to grow well, the volunteer group ${ }^{5}$ continued to pilot the cultivation of vegetables using greenhouses warmed with water from the hot springs. In the 1970s, while this cultivation technique was being developed, Japan implemented the Policy of Reducing Production to reduce surplus rice production. This gave the people of Nigorikawa area an opportunity to start full-scale geothermal greenhouse agriculture using the hot springs. With the help of the Special Rice Farming Conversion Project in fiscal 1970 (total budget of 22.5 billion yen), 54 greenhouses covering more than $8,515 \mathrm{~m}^{2}$ were built to make use of hot springs (grant rates of $66 \%$ ) and 24 farming households began the cultivation of half-forced and late-maturing cucumbers. Nigorikawa Geothermal Vegetable Farming Development Association (renamed Nigorikawa Geothermal Vegetable Farming Association in 1974) was established under Mori Agricultural Cooperative association and began to ship cucumbers in May 1971. Greenhouse agriculture using hot springs was thus introduced to avoid the collapse of local community.

Around 1973, crop rotation was introduced, with forced cucumbers harvested in spring (April to June), late-maturing tomatoes in autumn (September to November), and leafy vegetables such as cruciferous summer vegetables in winter (December to March). Harvest volumes and quality stabilized, and it soon became clear that a good income could be earned from this type of farming. Fluctuations in harvest volumes resulting from cold weather damage were low compared to paddy rice cultivation. Furthermore, the Policy of Reducing Production from fiscal 1971 onward offered additional payments for conversion to the group change to many-years crops. ${ }^{6}$ The Policy also strongly encouraged farmers to convert from paddy rice cultivation to greenhouse agriculture (Usui ed. 1994). As a result, 13 to 23 additional greenhouses using hot springs covering some $4,000 \mathrm{~m}^{2}$ were constructed throughout the 1970s, and the sales total of Nigorikawa Geothermal Vegetable Farming Association exceeded 100 million yen in 1977. A new rice classification system introduced in 1979 resulted in price slump of rice produced in Hokkaido because of its poor taste. Profitability of greenhouse agriculture increased on a relative basis. The sales of the association continued to rapidly grow, exceeding 150 million yen in 1980 and 300 million yen in 1989 .

In the 1970s, hydrothermal energy was first 
considered as a supplement to hot spring water. While development of alternative energy sources was driven by national policy after the oil crisis, the Geological Survey of Hokkaido investigated the heat released by Nigorikawa area from 1973 to 1974 . It estimated that $130^{\circ} \mathrm{C}$ water $(2,000$ $\mathrm{t} / \mathrm{h})$ and high-temperature steam $(500 \mathrm{t} / \mathrm{h})$ could be obtained by drilling 15 wells in the geothermal reservoir to a depth of $1,000 \mathrm{~m}$. Because the heat that could be generated by these wells was estimated approximately 125 times the heat of the flowing hot springs of the time, development of geothermal resources seemed promising. A few test wells drilled by Japan Metals \& Chemicals Co., Ltd. (JMC) confirmed the existence of a geothermal reservoir. JMC then established a subsidiary, South Hokkaido Geothermal Energy Co., Ltd. (SHG), which drilled 10 production wells (655-3,250 m deep) and reinjection wells (498-2,383 m deep) from 1977 to 1980 . The resulting hot water and high-temperature steam were piped to the Hokkaido Electric Power Co., Inc.'s Mori Geothermal Power Station, which began operation in 1982. After the hot water and high-temperature steam was used for power generation, the resulting $90^{\circ} \mathrm{C}$ water was used to heat greenhouses (Hasegawa 1986). Under the authorization of the New Improvement Projects for Agricultural Structures, 31 greenhouses were built in 1982-1983, with 3 more in 1986. 10 farming households set themselves up as Geothermal Greenhouse Utilization Association of Sumikawa 1st Area and began producing semi-forced $\mathrm{cu}-$ cumbers and late-maturing tomatoes. A second hot water greenhouse apartment complex was built along with 35 greenhouses in 1989, and the 7 farming households established Geothermal Greenhouse Utilization Association of Nigorikawa 1st Area to begin their agricultural business.

When the Rice Farming Activation Project was started in 1993, conversion to geothermal greenhouse agriculture was subsidized to a maximum of $70 \%$. When Hokkaido suffered a record cold summer in 1993, the Hokkaido harvest was given a Crop Situation Index rating of 40 (normal year $=100$ ). Nigorikawa is susceptible to cold weather damage in the summer as a result of the cold northeasterly wind that blows into the area during the summer, forming a dense fog. The 1993 crop failure stimulated rapid conversion from paddy rice cultivation to greenhouse agriculture. In 1994, 3 associations using hot springs and geothermal hot water centralized their packing and shipping as a result of a change in the destination of their tomato shipments. ${ }^{7}$ Shipments to the Kanto market were begun in 1991, and prices rose favorably. On the other hand, when the price of cucumbers fell below $200 \mathrm{yen} / \mathrm{kg}$, many greenhouses began growing only tomatoes all year round.

In 2000, the efficiency of harvesting, sorting and shipping processes increased with the completion of tomato processing facilities next to Nigorikawa branch of New Hakodate Agricultural Cooperative Association as a result of the Urgent Crop Change Program promoted by the national government. In the past, all members of a family farm would be busy sorting until midnight during peak season. Cooperative sorting removed labor constraints and increased consistency of quality. As a result of the increased use of greenhouses heated by hot springs and the planting of tomatoes instead of cucumbers and cruciferous summer vegetables, the land area devoted to high-value tomatoes increased rapidly. However, 5 farmers belonging to the Geothermal Vegetable Farming Association who already producing highquality tomatoes are continuing their own sorting and did not participate in the cooperative sorting. Although producing high-quality tomatoes requires considerable time and effort, the average price of these tomatoes is not much higher than those from the cooperative facilities. Even taking the commission ( $16.25 \mathrm{yen} / \mathrm{kg}$ including shipping charge) into consideration, cooperative sorting and shipping is more profitable.

The production of mizuna began to increase rapidly around 2002 , as a result of the search for products with higher profitability. After being introduced as a healthy vegetable on a TV program popular among housewives, demand for mizuna began to increase in Hokkaido as well. Prompt responses to trends helped farmers earn higher incomes. However, the importance of tomatoes continues to increase, with the total area planted each year reaching more than 40 ha in Nigorikawa in a normal year. At present, 15 of the 35 farmers in the Geothermal Vegetable Farming Association, 2 of the 7 farmers in the Greenhouse Utilization Association of Nigorikawa 1st 




Figure 8. Distribution map of geothermal greenhouse in Nigorikawa (2005). Source: Fieldwork.

Area, and all 10 farmers in the Greenhouse Utilization Association of Sumikawa 1st Area (1 of which also joined the Geothermal Vegetable Farming Association) produce only tomatoes in their geothermal greenhouses all year round. These farmers own 827 geothermal greenhouses (Figure 8), most of which are $50 \mathrm{~m}$ in length $\left(260 \mathrm{~m}^{2}\right)$.
Factors Contributing to the Success of Geothermal Greenhouse Agriculture in Nigorikawa

\section{Unique characteristics of location and hot spring rights}

As explained above, as a result of using geot- 
hermal greenhouses to primarily cultivate tomatoes, Nigorikawa area succeeded in reversing its depopulation to achieve remarkable development. This success has been realized through the effective use of the area's abundant geothermal resources. However, Nigorikawa is not the only area with abundant geothermal resources in Hokkaido. Therefore, the development of unique geothermal greenhouse agriculture in Nigorikawa cannot be explained solely by the existence of geothermal resources. Other influential factors are the superiority or inferiority of the area as a tourist resort and the right to hot springs for people to determine the use of the geothermal resources.

Tourism industry is the most profitable business to use hot springs. Even in Hokkaido, favorably located hot springs are frequently used for bathing and play an important role in the tourism industry, which forms the basis of Hokkaido's economy. Therefore, the conditions needed to effectively use geothermal resources for purposes other than tourism ${ }^{8}$ are as follows: 1) abundant sources of flowing hot water must be available, and 2) a hot spring tourist resort cannot be developed because the location is neither in the suburbs of Sapporo nor on the main tourist route. ${ }^{9}$ It is those areas with fertile alluvial lowlands around the settlement and where tourism development lags despite abundant nearby hot springs that are suitable for the agricultural use of geothermal resources. Nigorikawa area exhibits these characteristics.

In Nigorikawa area, hot springs can be found almost anywhere in the western part of the area by drilling about $50 \mathrm{~m}$, where the groundwater is shallow, or by drilling about $150-200 \mathrm{~m}$ in the center of the area. ${ }^{10}$ Because it is technically easy to dig a shallow well, 3 drilling associations organized by local volunteers, including managers of hot spring inns and former employees of a construction company, are excavating with their own equipment. As a result, the cost per metre of digging a well is lower in Nigorikawa area, at 10,000 yen, compared to the market price of 30,000 to 50,000 yen. If the excavated site is $150 \mathrm{~m}$ or more from the nearest hot spring source, drill boring can be used at no extra cost except for a few cases. ${ }^{11}$ However, because greenhouse agriculture is a means to attract peo- ple to an underpopulated area, the charging of premiums is an impediment to achieving this goal. It is also noteworthy that the owners of Nigorikawa area's hot spring inns, who should be able to claim those hot spring premiums, were the key people promoting geothermal greenhouse agriculture. The hot water needed for 7 hot spring tourism facilities is extremely low compared to the total amount of hot spring water flowing in Nigorikawa area, and its use for tourism does not prevent other uses. Furthermore, the cost of constructing a $50 \mathrm{~m}$ plastic greenhouse ranges from 200,000 to 300,000 yen because subsidies related to the change of ricepaddy crop can be used (with a subsidization rate of $50 \%$ to $75 \%$ ). Heating is as simple as running a plastic pipe filled with hot spring water and does not require a heater (costing 500,000 to 600,000 yen) or a warming machine (costing 1.0 to 1.2 million yen). Thus, geothermal greenhouse agriculture in Nigorikawa has a clear advantage in that it does not require significant initial outlays.

The cost of maintenance after digging is also reasonable. Apart from the cost of electricity to operate a compressor to force air into the well and thereby increase water pressure, the only cost is that for removing calcium inside the well hole every 10 years. Because the local drilling association performs this work, it costs only tens of thousands of yen. As for greenhouses heated by geothermal hot water, farmers using heat exchange equipment pay a user fee of 700,000 to 800,000 yen per year to SHG. However, geothermal hot water offers many advantages: it is less costly than burning heavy oil when the depreciation of the boiler is taken into account, and stable heating can be achieved, even in winter. Some farmers are able to receive the subsidy for changing crops from rice when the land to be used was originally paddy fields.

Therefore, conditions unfavorable to hot spring tourism resorts in turn create opportunities for the agricultural use of geothermal resources in Nigorikawa area. In addition to the shallow depth of the wells and the technological expertise available locally, the fact that the right to hot springs is almost worthless as a result of local historical circumstances contributes to reasonable initial outlays and reasonable operating 
costs for geothermal greenhouse agriculture. These locational characteristics of Nigorikawa area as a geothermal farming place of greenhouse tomato production can be considered a relative advantage.

\section{Crop selection and sales strategy}

Finding new markets as a result of shipping produce between traditional harvest seasons supports the development of greenhouse agriculture in Hokkaido. However, there is a limit to how much seasonal shifting can be done in a greenhouse. It is also necessary to have appropriate amounts of sunshine immediately before harvest. Because the average amount of daily sunshine in Nigorikawa area is low (200 cal/ $\mathrm{cm}^{2}$ per day) from December to February, it is not possible to grow greenhouse tomatoes for winter harvest. Moreover, late-maturing tomatoes harvested in the autumn sometimes experience very bad harvests in lean years such as 2002, when sunshine was lacking and temperatures were extremely low from summer to autumn. ${ }^{12}$

The price of tomatoes in the Tokyo market is the lowest from May to July each year (Figure 9). Local products grown outdoors come into season, and the monthly shipments reach $10,000 \mathrm{t}$, reducing the price to approximately $200 \mathrm{yen} / \mathrm{kg}$. Moreover, since tomato cultivation has dramatically changed as a result of the development of greenhouse agriculture, dependency on tomatoes grown in greenhouses has reached a high of $41 \%$, requiring monthly shipments of 5,000 to $6,000 \mathrm{t}$ even in winter. However, greenhouse tomato output is not always stable, as it depends on the weather conditions in each production area.

The season of tomatoes in Hokkaido is commonly from June to September. In contrast, the geothermal tomatoes in Nigorikawa come into season from September to November, when the price are higher. Supply of tomatoes becomes unstable if bad weather strikes the Kanto and Tohoku regions, the main autumn production areas. Seedlings are grown during the summer, which means that their cultivation must be carefully overseen, and they are susceptible to destruction by natural disasters such as typhoons. The price of tomatoes can fluctuate from 200 to $500 \mathrm{yen} / \mathrm{kg}$ within a short period of time (Table



Figure 9. Monthly unit price of tomato in 3 major markets (average price between 1999-2003).

Source: Agricultural Price Statistics.

1). However, the tomato farmers in Nigorikawa area rarely experience a financial loss on their harvest and shipment because the price of autumn-maturing tomatoes rarely falls below the price of summer tomatoes grown outdoors (approximately $200 \mathrm{yen} / \mathrm{kg}$ ) and the cost of production in Nigorikawa is as low as the cost of production for tomatoes grown outdoors. Accordingly, substantial profits can be earned when the price rises. On the whole, the price of autumn tomatoes has been slowly increasing since the second half of the 1980s as a result of year-round consumption. Mori Agricultural Cooperative Association, ${ }^{13}$ which is in charge of cooperative sales of Nigorikawa tomatoes, began shipping autumn maturing tomatoes to some wholesale markets in the Kanto region since 1991. In the autumn, the quality of local Kanto products tends to decline, often resulting in restricted supply and making it easier to earn a higher price there than in the Hokkaido market. Currently, $60 \%$ of Nigorikawa area's autumn tomatoes are shipped to Kanto markets, and the remaining $40 \%$ to Hokkaido markets.

For forced and semi-forced spring tomatoes harvested from April to June, prices are also on the rise relative to those of cucumbers, which must compete with imports of cucumbers (Figure 10). Spring tomatoes are not as affected by 
Table 1. Transition of the production in Mori town and the monthly unit price in Hokkaido on tomato and cucumber

\begin{tabular}{|c|c|c|c|c|c|c|c|c|}
\hline \multirow{2}{*}{ Year } & \multicolumn{2}{|c|}{$\begin{array}{l}\text { Production in } \\
\text { Mori town (t) }\end{array}$} & \multicolumn{4}{|c|}{ Monthly unit price of tomato (yen $/ \mathrm{kg}$ ) } & \multicolumn{2}{|c|}{$\begin{array}{l}\text { Monthly unit price of } \\
\text { cucumber (yen } / \mathrm{kg} \text { ) }\end{array}$} \\
\hline & Tomato & Cucumber & May & June & October & November & May & June \\
\hline 1975 & 137 & 154 & 229 & 186 & 212 & 240 & 200 & 104 \\
\hline 1976 & 202 & 364 & 202 & 176 & 106 & 192 & 187 & 165 \\
\hline 1977 & - & - & 381 & 234 & 151 & - & 206 & 192 \\
\hline 1978 & 395 & 451 & 325 & 197 & 168 & 113 & 248 & 198 \\
\hline 1979 & 430 & 576 & 351 & 237 & 166 & 274 & 212 & 219 \\
\hline 1980 & 430 & 554 & 344 & 244 & 113 & 205 & 193 & 186 \\
\hline 1981 & 345 & 472 & 497 & 268 & 186 & 166 & 231 & 244 \\
\hline 1982 & 457 & 606 & 403 & 245 & 167 & 165 & 214 & 145 \\
\hline 1983 & 373 & 638 & 369 & 243 & 211 & 221 & 224 & 182 \\
\hline 1984 & 648 & 962 & 319 & 234 & 206 & 174 & 216 & 163 \\
\hline 1985 & 585 & 595 & 402 & 245 & 166 & 210 & 204 & 165 \\
\hline 1986 & 599 & 770 & 388 & 260 & 176 & 270 & 239 & 153 \\
\hline 1987 & 663 & 821 & 449 & 274 & 236 & 267 & 202 & 180 \\
\hline 1988 & 669 & 916 & 459 & 269 & 240 & 275 & 211 & 156 \\
\hline 1989 & 776 & 1,054 & 477 & 330 & 284 & 369 & 236 & 198 \\
\hline 1990 & 974 & 1,170 & 476 & 274 & 348 & 505 & 476 & 274 \\
\hline 1991 & 976 & 1,490 & 452 & 281 & 291 & 450 & 212 & 210 \\
\hline 1992 & 981 & 1,290 & 499 & 374 & 256 & 282 & 210 & 261 \\
\hline 1993 & 951 & 1,130 & 429 & 353 & 287 & 316 & 242 & 235 \\
\hline 1994 & 1,450 & 1,160 & 402 & 336 & 427 & 494 & 180 & 184 \\
\hline 1995 & 1,660 & 624 & 409 & 371 & 276 & 411 & 304 & 237 \\
\hline 1996 & 1,590 & 540 & 446 & 376 & 222 & 224 & 213 & 324 \\
\hline 1997 & 1,600 & 407 & 455 & 321 & 378 & 400 & 314 & 194 \\
\hline 1998 & 1,850 & 354 & 457 & 341 & 377 & 528 & 282 & 193 \\
\hline 1999 & 2,650 & 611 & 396 & 329 & 458 & 572 & 335 & 227 \\
\hline 2000 & 2,950 & 413 & 309 & 298 & 344 & 325 & 233 & 210 \\
\hline 2001 & 3,030 & 386 & 316 & 307 & 257 & 269 & 213 & 212 \\
\hline 2002 & 2,170 & 358 & 330 & 271 & 251 & 406 & 270 & 241 \\
\hline 2003 & 2,170 & 334 & 347 & 252 & 244 & 242 & 253 & 180 \\
\hline 2004 & 1,980 & 322 & 280 & 284 & 352 & 450 & 319 & 205 \\
\hline
\end{tabular}

Source: Annual Report of Agriculture, Forestry and Fishery Statistics in Hokkaido.

the weather as autumn tomatoes and are thus able to obtain stable, higher prices. Accordingly, many farmers have changed their spring crops from cucumbers to tomatoes in the 1990s. Moreover, April to June is when Tokyo markets start bringing in Kanto products grown both in greenhouses and outdoors, largely reducing the prices of the products. On the other hand, when spring finally comes to Hokkaido, it cannot meet all of the demand only with local greenhouse tomatoes, resulting in the import of tomatoes from other prefectures at high transportation cost. Thus, the price of tomatoes in Hokkaido markets, including Sapporo and Hakodate, far exceeds prices in Tokyo markets during the spring. Almost all of the spring tomatoes produced in Nigorikawa are thus shipped to Hokkaido markets to obtain high prices.

Rising tomato prices are also affecting the other crops grown in the greenhouses of Nigorikawa. Previously the greenhouses used a three-crop system of spring cucumbers, autumn tomatoes and winter leaf vegetables. Production of leaf vegetables declined first, because their price was almost the same as that of products grown outdoors. Cucumber cultivation then declined in the 1990s. At present, of the 51 farming households operating geothermal green- 


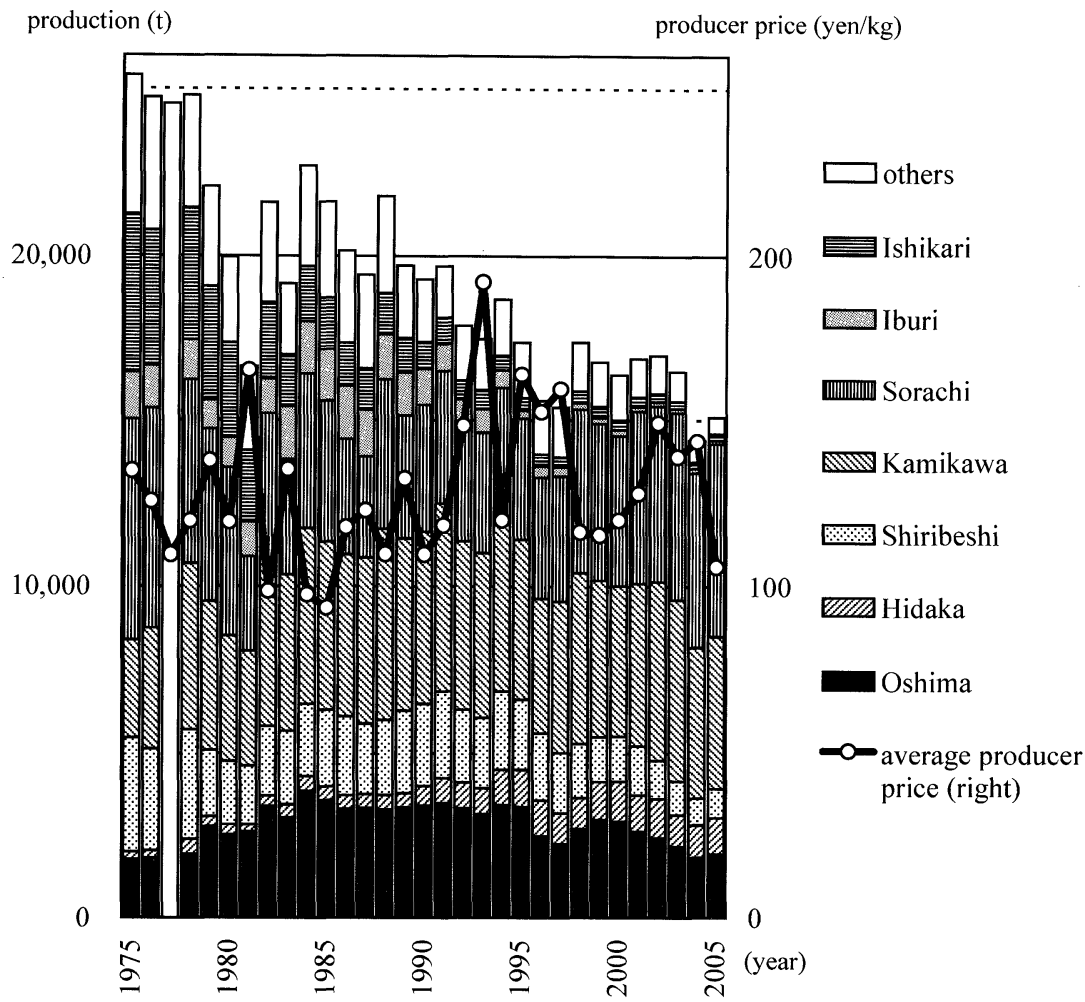

Figure 10. Transition of the averageproducer price and production by region of cucumber in Hokkaido. Source: Annual Report of Agriculture, Forestry and Fishery Statistics in Hokkaido.

houses, 21 exclusively deal in spring and autumn tomatoes, concentrating their resources on tomatoes that can obtain high prices by shipping between seasons. On the other hand, it is equally noteworthy that these farmers are flexible in terms of switching to new highly profitable products, for example, by swiftly responding to a sudden increase in demand for mizuna.

As a result of careful breeding and more market-oriented sales strategies, farmers now earn an average annual price of 300 to $350 \mathrm{yen} / \mathrm{kg}$ for greenhouse tomatoes. The average annual agricultural gross income per farming household is 15 million yen, including 13 million yen from tomatoes. The largest farmer in Nigorikawa earns 30 million yen of annual gross income. Because expenses can be reduced through the use of geothermal resources, their net income is also high. The annual net income of farmers in Nigorikawa averages 7 million yen, with the largest reaching 15 million yen.

\section{Sustainable Characteristic of Nigorikawa as a Geothermal Greenhouse Agricultural Area}

Given the potential for high agricultural earnings, there are many young people who consider taking over their parents' farming businesses in Nigorikawa. Among the 52 households currently engaged in greenhouse agriculture, more than 30 households have successors to their farming activities. Moreover, Nigorikawa is the region where family-run business arrangements are most diffused within Hokkaido and transfer of management to successors is progressing steadily. In most cases, the managerial prerogative is transferred to the successors when the parents reach 60 years of age and become eligible to receive farmers' pension. This heightens the incentive to engage in farming among the younger generations and motivate them to organize study groups to work diligently for im- 
provement.

Unfortunately, it is not certain whether the successor generation will be able to maintain the successful models of greenhouse agriculture achieved by the current parent generation for several decades into the future. There are many factors that undermine the sustainability, including depletion of geothermal resources and reduction of soil fertility.

\section{Depletion of geothermal resources}

The main factor that allowed Nigorikawa area to succeed in improving its competitiveness as a farming place of greenhouse tomato production was utilization of geothermal resources to secure advantageous production conditions. Currently, however, the number of wells using for greenhouse agriculture is as high as approximately 200. Due to excessive utilization of geothermal hot water and hot spring water, the available amount of geothermal resources is being reduced, the hot spring water is becoming depleted and the temperature is becoming unstable. Such adverse impact is particularly significant in the central to eastern parts of the basin where the ground-water level has been low from the start. ${ }^{14}$

Serious problems are occurring at wells for agricultural purposes; quite a few greenhouses have already been shut down because of this problem. There is a heap of abandoned and ruined geothermal greenhouses to the north of the elementary school. These greenhouses were also abandoned due to the reduction of amount and temperature of hot spring water. The hot spring water production is outrageously unstable; almost boiling hot spring water suddenly turns into lukewarm water with temperatures of less than 50 degrees Celsius, or hot spring water gushing out with great force loses the force from one moment to another.

Geothermal hot water production wells are also unable to secure the energy volume expected at the start of geothermal development. Yasukawa et al. (2005) point out that the superfluous pumping of geothermal hot water used for power generation caused change of reservoir pressure and drain of geothermal resources. SHG had dug ten production wells by 1980 , but these had to be abandoned one after another due to depletion of resources. SHG thus drilled four new production wells during the latter half of the 1980s and 11 more in 1991 to 1992, but the majority of them have already been abandoned. Even if it drills more wells, the production of geothermal hot water and high-temperature steam will start to decrease just a few years after the digging. The large amount of capital investment in these wells has hurt SHG's business performance, and it has been wasting spare resources in the process. After the bankruptcy of SHG in $2004,{ }^{15}$ its production facilities and so forth were transferred to Hokkaido Electric Power Co., Ltd. Geothermal hot water has so far been supplied to the geothermal hot water greenhouse complexes in the region as before. However, the rate of operation of the geothermal power station is down to only about $50 \%$ of the declared power $(50,000 \mathrm{kw})$, and it doesn't pay them at all. As the electric power industry has been deregulated, the outlook for the geothermal power station is becoming increasingly insecure and the fear of instability of the geothermal hot water supply is becoming stronger.

\section{Aggravation of negative side effects of repeated cultivation}

In greenhouse agriculture, where the land utilization intensity is high, aggravation of negative side effects of repeated cultivation is a serious problem that can threaten the continued existence of production centers. In Nigorikawa area as well, where the number of farms that specialize in double cropping of tomatoes in both spring and fall increases, the reduced quantity and quality of the crops due to aggravation of repeated cultivation is becoming a serious problem. In order to alleviate this problem, some old geothermal greenhouses keep rotating crops to reduce the negative effects of deterioration in the quality of soil, even if this results in low profitability. More fields are compelled to be left without crops for certain terms to give them some much-needed rest. However, many farmers cannot afford to do so, because it would lead to reduced earnings. It is reported that not a few greenhouses are rebuilt on different fields by utilizing agricultural subsidies. Disease endurance is prioritized when selecting species as well, and more and more farmers are employing Reiyo and 
Momotaro Colt, instead of conventional Momotaro.

In 2003 , as a countermeasure against the aggravation of repeated cultivation, Mori branch of New Hakodate Agricultural Cooperative Association invested 10 million yen in the purchase of two machines to disinfect soil by steam and hot water. These machines aim to prevent and eliminate diseases and pests in the entire greenhouse by filling with high temperature steam or pouring hot water of 70 to 95 degrees Celsius in the soil, both are produced by burning crude oil in a boiler. Unfortunately, these machines kill useful microorganisms as well, and the effect reaches only about $20 \mathrm{~cm}$ into the ground. Although they are very expensive machines, they are only able to disinfect one greenhouse per day. This means that, although a certain level of results can be achieved in this way, they are not the definitive means to solve the problem of aggravation of negative side effects of repeated cultivation.

Finally, it is thus unavoidable to increase the amount of agricultural chemicals applied to the soil in order to suppress generation of diseases and pests. However, as consumer demands for safety of agricultural products are becoming stronger and stronger, it is obviously unavoidable and becoming a pressing issue both to establish the traceability and to reduce the amount of agrichemicals immediately. For this reason, an almanac for reduction and prevention of agrichemical usage has been employed since fiscal year 2003 in an attempt to keep the number of times of spraying as low as possible and to promote switching to less toxic agricultural chemicals. Nonetheless, progress is undeniably slow because they barely managed to break away from the conventional cultivation methods under the guidance of New Hakodate Agricultural Cooperative Association after the merger. This may be partly due to the fact that the farmers mostly depend on cooperative sales and consumers and producers rarely get into direct contact with one another.

\section{Intensified competition among production centers}

Although the best season of tomato is early summer, fresh tomatoes are available at the storefront of supermarkets all year round. Along with cucumbers and bell peppers, tomatoes can be counted as one of the representative vegetables, for which new, all-year demands led to a stable market for vegetables grown in greenhouses. In fact, in greenhouse agriculture, tomatoes are considered to be one of the crops with the highest profitability.

However, this also means that there are many production centers that enter the market, attracted by the high profitability, and the competition among production centers is becoming increasingly intense. Biratori town in the Hidaka subprefecture, which is particularly famous for the "Nishipa's Lover" brand with outstanding competitive power, now enjoys the largest tomato yield $(8,670$ tons $)$ in Hokkaido. Biratori town achieved phenomenal growth, increasing its sales volume by approximately ten times in ten years. Biratori town is followed by Yoichi plain in the Shiribeshi subprefecture (Yoichi town 2,760 tons and Niki town 2,000 tons), where the climate is milder than in other areas in Hokkaido. Mori town (2,430 tons), which ought to have advantages in terms of production costs, as well as Sunagawa city in the Sorachi subprefecture (2,340 tons) and Biei town in Kamikawa subprefecture $(2,220$ tons) are forced to reconcile themselves to the third group.

There are no big differences in the volume of tomato production per farm among these production centers. In Nigorikawa area, all farming households with successors and high management incentive mainly engage in greenhouse agriculture, including tomato production. This means that it is impossible to gain new entry into tomato farming in Nigorikawa area, different from other emerging tomato production centers where new entry into the market is possible by the conversion from paddy rice cultivation. Moreover, the existing farming households have almost completely used up the family labor force, and have serious concerns about the depletion of geothermal resources. Although a little less than 20 farming households attempt to pursue aggressive business strategies by employing parttime workers and using other ways, the room for increasing production by extensive development is becoming increasingly scarce.

Recently, more and more farming households 
specialize in growing tomatoes, even though they run the risk of aggravation of negative side effects of repeated cultivation. One of the reasons is that it is necessary to secure a considerable shipment volume to establish brand names through conventional methods; for example, "Nishipa's Lover" by Biratori town did not succeed in cultivating potential outlets and increasing its sales unit prices until the mid-1990s, when a significantly large shipment volume was secured and the presence in the market was widely recognized. Mori branch of New Hakodate Agricultural Cooperative Association, which sells tomatoes grown in Nigorikawa, also desires to branch out to the Ota market in Tokyo eventually-a dream shared by many vegetable production centers. Under the current conditions, however, it is not possible to secure the lot volume demanded by the market and there is no prospect to win in the competition against existing leading production centers. That is the main reason why the shipments towards outside Hokkaido are primarily directed at local markets. Furthermore, among the 51 tomato farming households, approximately 20 have not succeeded in securing successors, and there is a high possibility that the current manager generation will retire or abandon farming. There is a strong concern that the relative decline of the production center may lead to a corresponding reduction of the competitive edge and thus in the selling unit prices. In other words, the growth of Nigorikawa as a tomato production center in greenhouses is reaching saturation, according to the conventional development model.

\section{Conclusion}

Nigorikawa area in Mori town is a pioneering production center of tomatoes grown in greenhouses in Hokkaido. Since the promotion of greenhouse agriculture was started as the master card in the measures against the excessively declining population in 1970, it has developed into the main key industry supporting Nigorikawa area. The success relied on intensive utilization of geothermal resources for agricultural purposes, which made economic sense because the rights of access to hot springs were almost of no value since the region was situated in a dis- advantageous location as a hot spring tourist resort. As it was not necessary to drill deep in order to create hot spring wells and some farmers were able to access geothermal hot water piped from Mori Geothermal Power Stations, both initial costs and running costs were extremely low. Moreover, the region succeeded through group efforts, to a certain extent, in clearing the inevitable technical barriers inherent in greenhouse agriculture. As a result, it became possible to pursue profitability by specializing in tomato growing, and the region succeeded in earning high incomes and securing successors.

The actual condition today, however, is that it is questionable whether it is possible to maintain sustainability as a production center via greenhouse agriculture using geothermal resources. In particular, the issue of depletion of geothermal resources has become serious. Since it does not cost a significant amount of money to acquire access rights to hot springs, and it is possible to drill hot spring wells freely as far as certain distances are kept, the water level is steadily being reduced and the water temperature is becoming unstable due to excessive drawing up of water. The construction of Nigorikawa Agricultural Dam which aimed to prevent land disaster on the upstream is also considered to contribute to the reduction of the groundwater level. This depletion of geothermal resources makes it difficult to expand tomato farming by geothermal greenhouses. As a result, it is clear that the growth of the production volume has hit the peak and the region is unable to secure the lot scale necessary to be recognized as a production center in a large market. In order to promote sustainable usage of geothermal resources, it is considered necessary to re-assess the amount of geothermal resources by some independent organization and promote resource cultivation measures, including tightening up of the regulations on drilling new wells. Moreover, it is also feared that the production center will shrink further as the people involved in farming gradually retire without anyone to take over the farms.

On the other hand, problems related to aggravation of negative side effects of repeated cultivation became worse as rotation farming systems were abandoned in pursuit of profitability. Since the locations suitable for construction of green- 
houses are restricted by the presence of hot spring sources, the greenhouses cannot be easily relocated when problems caused by the repeated cultivation occur. Thus, it is basically unavoidable to use large amounts of chemicals to suppress outbreaks of diseases and pests, and the region has not been able to fully satisfy the increased consumer awareness of reduced agrichemical farming. In other competing production centers, such as Biratori town, on the other hand, there are many examples where the production centers obtain benefits by expanding their production scales and establishing systems to produce large volumes of high quality tomatoes at low cost in order to secure a strong competitive edge. Compared to such production centers, the tomatoes produced in Nigorikawa seem to be lacking large-scale market power in terms of both price and quality. That is why the majority of the shipments to locations outside Hokkaido is destined to local markets where prices are relatively low.

There appear to be two possible strategies that Nigorikawa can take as a tomato production center. One of the options is a strategy to secure a large market share by scaling up the production and making their brand better recognized in order to be able to increase the unit price. In order for this strategy to succeed, it seems to be necessary to find a new heat source technology for heating the greenhouses. Rather than depending solely on geothermal resources, a new model that combines geothermal resources and fossil fuels in a smart manner must be constructed. Furthermore, it is necessary to make the farmers themselves aware of the initiatives required in order to pursue large-scale production, such as aggressive introduction of employed labor force and establishment of rotation farming systems for maintaining soil fertility.

Another option is a strategy to create higher added value by pursuing high-quality produce with significantly reduced utilization of chemicals. The Japanese economy is currently achieving stable growth rates and consumption is regaining momentum, but at the same time various problems related to safety of foods have been occurring quite frequently. Influenced by these trends, the consumer demands for "safe and secure" agricultural products are growing rapidly.
In fact, there is a strong tendency that the consumers choose tomatoes whose quality they are sure of, even if they are slightly more expensive, as represented by the fact that sales volume of "Kokumi Tomato" by Kagome Co., Ltd. recently reached 4 billion yen. It is considered that the time has come for the farmers in Nigorikawa to examine strategies for pursuing products with higher added value. That is, it is necessary to shift from the Fordism-style greenhouse tomato farming system that pursues only productivity, to the post-Fordism system that prioritizes quality. However, with the current sales strategies, it is difficult to connect improvements of quality to increased profits. A radical shift of the sales strategies towards promotion of brand names emphasizing environment-friendly "greenhouse agriculture" and making aggressive efforts in contract farming, is mandatory. Moreover, it is necessary to reinforce the activities of organizations that assist the farmers in helping each other with research, which is essential in improving quality, as well as to establish rotation farming systems to reduce the load on the soil.

When selecting the latter option, in particular, it is predicted that effective support cannot be provided with the conventional agricultural policies. For example, Nigorikawa Agricultural Dam was constructed devoting approximately 30 years of time on the upstream of Sumikawa river flowing in the east part of Nigorikawa with the purpose of "preventing agricultural land and facilities from flood damage". The dam, which was built by the agricultural budget, never contributed to promote agriculture in Nigorikawa area, and ought to be its beneficiary. ${ }^{16}$ On the contrary, the groundwater level in the eastern region decreased due to the construction of the Dam, and hot spring resources are also being exhausted or depleted as a consequence. It is especially emphasized here that the agricultural budget must be spent to support farming activities of motivated farmers.

\section{Acknowledgments}

A summary of this paper was presented at the Autumn Meeting of the Association of Japanese Geographers at Hiroshima University in September 2004, and at the Northeastern Local Meeting of the Japan Association of Economic Geographers in August 2004. I 
wish to thank Prof. Seki and Prof. Hashimoto (Hokkaido Univ.), and Mr. Fujimoto (the Geological Survey of Hokkaido) for their special cooperation. This study was financially supported by a research grant from the Hokkaido Development Association.

(Received 18 September 2005)

(Accepted 12 July 2006)

\section{Notes}

1. The consumption of petroleum is increasing rapidly accompanied with rapid economic growth in some developing countries including China. The price of West Texas Intermediate (WTI) of New York Mercantile Exchange (NYMEX), which is used as the index of the international market condition of crude oil, was changing to around 20 dollars per barrel in the $1990 \mathrm{~s}$, and rose in price to about 70 dollars after 2000 . It soared rapidly after 2004, and it reached as much as 70 dollars per barrel in September 2005.

2. The government attempted to improve the low productivity of marginal land by investing enormous amounts of public funds in numerous subsidized land improvement projects. Now, the average Hokkaido farm (16.9 ha) is 13.7 times the size of the national average (1.2 ha), and the average Hokkaido farm's agricultural income ( $¥ 3,560,000$ ) is 3.4 times that of the national average ( $¥ 1,034,000$ ).

3. Non-farming families generally consist of single elderly people, civil servants and school teachers.

4. The rice harvest was successful in 1920 after years of attempting to overcome the cold climate (Nigorikawa kaitaku 100 nen soumubu ed. 1997)

5. Leader of the group was a hot spring inn owner, son of a farmer in Ono town, who had been adopted into his wife's family in Nigorikawa after graduating from an agricultural high school.

6. The Policy of Reducing Production involves both control of rice production control and the promotion of the farming of other crops. Farmers received, for every 10 ha, 5,000 yen more than if they used the regular change of crops and 10,000 yen more than if they took their land out of production.

7. Each of the 3 associations had been collecting and shipping tomato until 1993. However, since it was revealed that a certain wholesaler in Hakodate had got a large amount of profits by resale to an other company in the same trade, dealings with the company were stopped. This trouble brought tomato farmers to the common recognition that it is indispensable to make joint col- lecting and shipping system through the agricultural cooperative association.

8. Kitayuzawa spa in Otaki village, Iburi subprefecture, has encouraged the development of social welfare facilities, such as a hospital, a home for the aged and a rehabilitation center. Hot springs are also used for home heating in Shiraoi town (Iburi subprefecture) and Teshikaga town (Kushiro subprefecture), although agriculture is difficult to undertake in these areas because of the volcanic ash making up the soil.

9. Many of the tourists who visit southern Hokkaido choose Hakodate for accommodation, and go directly to Noboribetsu spa or Sapporo, passing straight through Nigorikawa spa.

10. Many well-known resorts in Hokkaido are now facing the problem of declining hot spring sources. It is becoming increasingly difficult to drill new wells. The only way out to obtain new hot spring source is a deep drilling method able to exceed $1,000 \mathrm{~m}$. Such drilling, however, is quite expensive (30 to 100 million yen) and does not necessarily result in a productive hot spring.

11. In prefectures other than Hokkaido, natural hot springs and shallowly dug hot springs are considered local resources and are usually managed by rural communities such as property wards. The drilling premium may cost millions of yen, assuming that a drilling license can be obtained. It is quite difficult to transfer and sell the former customs right to use hot springs. However, the customary right to hot springs did not originally exist in Hokkaido, a newly reclaimed land (Mori 2001). This has allowed promotion of effective use of geothermal resources for purposes other than tourism.

12. The daylight hours in Aug. 2002 in the Yakumo AMEDAS were only 65.8 hours equivalent to about $60 \%$ of a normal year (115.1 hours).

13. Though New Hakodate Agricultural Cooperative Association was inaugurated by a merger of 13 cooperatives in Oshima and Hiyama subprefecture in Feb. 2002, Mori branch (former Mori Agricultural Cooperative Association) has the authority to decide tomato sales as usual at present.

14. To take a few examples, some twenty years ago, there was a spring in the woods behind the elementary school in the central part of the basin, from which hot water used to gush out in such quantities that people could cook eggs in it. Now, however, the ground was not even steaming. In a hot spring inn near the elementary school, there used to be an abundance of hot water, which would flow out naturally even from cracks at the 
bottom of the bath tubs. Now, the amount of hot water has been severely reduced although the water temperature is basically maintained. The hot water supply was recovered once by performing drilling works again several years ago, but it is said that the hot water is already becoming seriously reduced again recently. Another inn, although it has no problem in the amount of hot water, is experiencing problems because the water temperature is decreasing.

15. The sales volume of SHG, which amounted to 3.37 billion yen during the fiscal year of 2000 , dropped sharply to 2.04 billion yen in the fiscal year of 2003. In April 2004, SHG went bankrupt with a debt of approximately 25 billion yen as it ran into serious financial trouble, partly due to the impact of bankruptcy of JMC, the parent company of SHG.

16. It was attacked by unprecedented local severe rain in September 1994, and all roads to Nigorigawa were closed for one week. However, there was almost no agricultural damage with a good harvest both of tomato and rice.

\section{References}

Araki, H. 1996. Growth of vegetable production in Asahikawa, Hokkaido: Strategies of shipper's union. The Human Geography 48: 427-448. (JE)

Bowler, I.R. ed. 1992. The geography of agriculture in developed market economies. Harlow UK: Longman Scientific \& Technical.

Facchini, U. Magnoni, S. and Sordelli, C. 1993. Rodigo 1, Northern Italy: A geothermal complex for agriculture. Geothermics 22: 135-147.

Fujimoto, K. 1997. Energy estimation of pumping geothermal water. Report of the Geological Survey of Hokkaido 68: 137-140. (J)

Fujimoto, K., and Matsunami, T. 1999. Hokkaido ni okeru chinetsu onsen riyou no genjou 1998 (Present state on utilization of geothermal energy and hot spring in Hokkaido 1998). Sapporo: The geological survey of Hokkaido. (J)

Hasegawa, S. 1986. Hokkaido Mori machi no nessui riyou shisetu to sono riyou joukyou (Facilities for geothermal hot water and its utilization situation in Mori town, Hokkaido). Journal of the Japan Geothermal Energy Association 23: 117-132. (J)

Ishihara, T. 1996. Mondai chiiki to kokusai kyousou (Problem regions and international competition: The development of agriculture and tourism). Tokyo: Taimeido. (JE)

Kamano, Y. 2000. Chinetsu kaihatsu to chiiki shakai no hendou: Mori machi Nigorikawa chiku wo jirei to shite (Development of geothermal energy and change of regional society: A case study of Nigorikawa area in Mori town). Graduate Thesis, Faculty of Letters, Hokkaido University. (J)

Kurozumi, H., and Doi, N. 2003. Inner structure of the Nigorikawa caldera, Hokkaido, Japan. Bulletin of the Volcanological Society of Japan 48: 259274. (JE)

Lund, J. W., and Boyd, T. L. 2000. Geothermal directuse in the United States update: 1995-1999. Proceedings World Geothermal Congress 2000: 297-305.

Lund, J. W., and Klein, R. 1995. Pravin park: Taupo, New Zealand. Geo-Heat Center Quarterly Bulletin 16(4): 27-29.

Mori, K. 2001. Onsenken to onsenchi kouzou: Hokkaido Kita-yuzawa onsen to Yamanashiken Shimobe onsen no jirei kara (Right of hot spring and structure of spa resort: From a case study of Kita-yuzawa spa in Hokkaido and Shimobe spa in Yamanashi Prefecture). Graduate Thesis, Faculty of Letters, Hokkaido University. (J)

Nakajima, H. 1984. Chinetsusui riyou no shisetsu engei: Nigorikawa chiku ni okeru hatten youin to kongo no tenbou (Greenhouse agriculture by using geothermal hot water: Development factors and future view in Nigorikawa area). Kihou nourin toukei (Seasonal Bulletin of Agricultural and Forestry Statistics) 67: 1-17. (J)

Nigorikawa kaitaku 100 nen soumubu (Administrative division of 100-years memorial of Nigorikawa exploitation) ed. 1997. Nigorikawa 100 nen no ayumi: Kita no tougenkyou (100-years history of Nigorikawa: Northern Shangri-La). Hokkaido: Nigorikawa 100 nen kinen jigyou kyousankai (Cosponsor association for 100-years memorial enterprise of Nigorikawa exploitation). (J)

Popovski, K., and Popovska-Vasilevska, S. 2001. Feasibility of geothermal agricultural projects at the beginning of XXI century. Geo-Heat Center Quarterly Bulletin 22(3): 38-46.

Popovski, K., and Popovska-Vasilevska, S. 2003. Prospects and problems for geothermal use in agriculture in Europe. Geothermics 32: 545-555.

Sakamoto, H. 2002. Yasai Engei no sanchi bunseki (Analysis on vegetable horticultural area). Tokyo: Taimeido. $(\mathrm{J})$

Takesono, T. 2002. Shisetsu engei gijutsu no shinten (Technological progress of greenhouse agriculture). In Nourin suisan kenkyu bunken kaidai 16: shisetsu engei hen (Bibliographical introduction to research on agriculture and forestry 
16: Greenhouse agriculture). Tokyo: Nourin toukei kyoukai (Association of Statistics on Agriculture, Forestry and Fisheries). (J)

The Geological Survey of Hokkaido. 1975. Nigorikawa chiku ni okeru chinetsu no tamokuteki riyou ni tsuite (About multiple-purpose use of geothermal energy in Nigorigawa area). Sapporo: The Geological Survey of Hokkaido. (J)

Usui, S. ed. 1994. Daikibo inasaku chitai no nougyou saihen: tenkai katei to sono kiketsu (Agricultural reorganization in large-scale rice-farming districts: Development process and its result). Sapporo: Hokkaido University Press. (J)

Yasukawa, K., Ishido, T., and Suzuki, I. 2005. Geothermal reservoir monitoring by continuous self-potential measurements, Mori geothermal field, Japan. Geothermics 34: 551-567.

$(\mathrm{J})$ : written in Japanese

(JE): written in Japanese with English abstract 